\title{
Reconstruction of the Achilles tendon using quadriceps tendon graft in bilateral xanthomas secondary to familial hypercholesterolemia: A case report
}

\author{
Ailesel hiperkolesterolemi zemininde iki taraflı Aşil tendon ksantomasının \\ kuadriseps tendon grefti ile rekonstriksiyonu: Olgu sunumu
}

\author{
Yaşar Mahsut Dinçel(D, MD, Yavuz Arıkan (D), MD, Devrim Özer (D, MD, Seçkin Basılgan (D), MD \\ Department of Orthopedics and Traumatology, Metin Sabancı Baltalimanı Bone and Joint Diseases \\ Training and Research Hospital, İstanbul, Turkey
}

\begin{abstract}
Achilles tendon xanthomas are rarely seen masses that are highly associated with hyperlipidemia. They are manifested in two types: Xanthomas developed secondary to familial hypercholesterolemia and cerebrotendinous xanthomatoses. In this report, we present a case of bilateral Achilles tendon xanthoma secondary to familial hypercholesterolemia and resection along with a portion of the Achilles tendon. The patient was a 49-year-old male who presented to our clinic with complaints of difficulty walking and swelling in both heels. The swellings had started insidiously without a trauma history. The xanthomas were operated at different time points, albeit with the same surgical technique. Quadriceps tendon graft and flexor hallucis longus transfer was used for autografting. Xanthoma should be considered in cases with swellings in the Achilles tendon. Total resection is necessary to avoid recurrence of the xanthomas. Large gaps formed after resection can be filled and reconstruction of the Achilles tendon can be realized using quadriceps tendon autografts (containing bony fragments) and the flexor hallucis longus tendon. We believe a functional ankle and an Achilles tendon can be achieved with the employment of this technique.
\end{abstract}

Keywords: Achilles tendon; familial hypercholesterolemia; flexor hallucis longus transfer; quadriceps tendon graft; swelling; xanthoma.
$\ddot{O} Z$

Aşil tendonunu ksantomaları, nadir görülen, hiperlipidemi ile yüksek oranda ilişkili kitlelerdir. İki farklı tipi vardır: Ailesel hiperkolesterolemi zemininde ksantomozlar ve serebrotendinöz ksantomatozlar. Bu olguda, hiperkolesterolemi zemininde, iki taraflı Aşil tendonundaki ksantomalar, Aşil tendonunun bir bölümü ile birlikte rezeke edildi. Hasta, yürüme zorluğu ve her iki topukta şişlik şikayetleri ile kliniğimize başvuran 49 yaşında bir erkekti. Şişlikler travma öyküsü olmadan sinsice başlamıştı. Ksantomlar aynı cerrahi teknikle de olsa farklı zamanlarda ameliyat edildi. Otogreft için kuadriseps tendon grefti ve fleksör hallucis longus transferi kullanıldı. Aşil tendonu şişliği olan olgularda ksantoma göz önünde bulundurulmalıdır. Ksantomaların rekürrensini önlemek için tamamen rezeke edilmeleri gereklidir. Rezeksiyon sonrası ortaya çıkan büyük boşluklar ve Aşil tendon rekonstriksiyonu; kuadriseps tendon otogrefti (kemik içeren) ve flexor hallucis longus tendonu kullanılarak yapılabilir. Bu teknik ile fonksiyonel bir ayak bileği ve Aşil tendonu elde edilebileceğine inaniyoruz.

Anahtar sözcükler: Aşil tendon; ailesel hiperkolesterolemi; flexor hallucis longus transferi; kuadriseps tendon grafti; şişlik; ksantoma.
Achilles tendon xanthomas are rarely seen masses. They are highly associated with hyperlipidemia ${ }^{[1]}$ and manifest themselves in two types: Xanthomas developed secondary to familial hypercholesterolemia $(\mathrm{FH})$ and cerebrotendinous xanthomatoses (CTX). Cerebrotendinous xanthomatosis is a disorder caused 

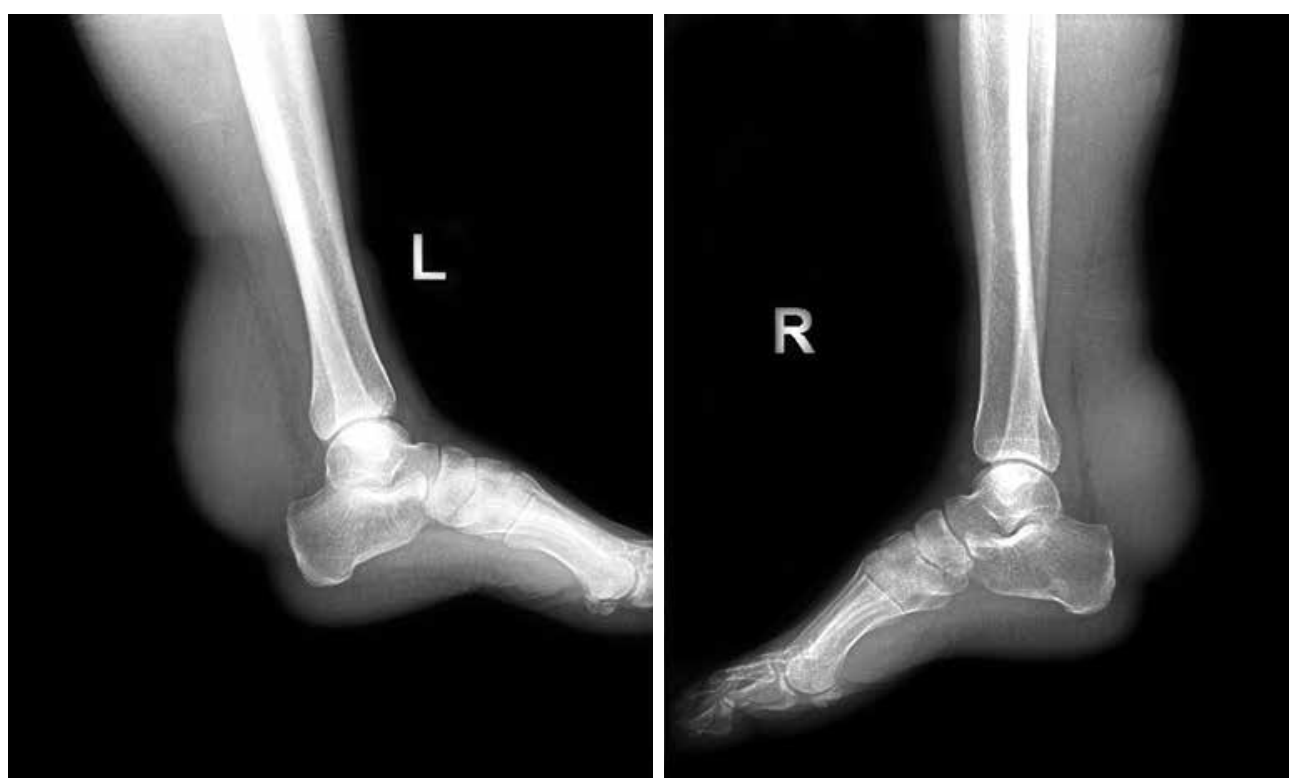

Figure 1. Preoperative X-rays of the left and right ankles. Soft tissue density masses can be seen in both ankles.

by a mutation of the sterol 27-hydroxylase gene (CYP27) resulting in the accumulation of cholesterol and cholestanol..$^{[1]}$

Xanthomas secondary to $\mathrm{FH}$ are disorders exhibiting deterioration of the lipid metabolism..$^{[2]}$ Deterioration of lipid metabolism is a disorder characterized by the accumulation of lipids in the cells, skin and the visceral organs. The condition may present with or without abnormal serum lipids. ${ }^{[3]}$ Xanthomas may involve the tendon, ligament, fascia or the periosteum. ${ }^{[4]}$ Tendinous xanthomas consist of hard, flat, and deep nodules, typically covered by normal skin and are mostly found on the hands, knees, elbows, and Achilles tendons. In general, both the patients and their families show increased levels of serum cholesterol. ${ }^{[5]}$ The metacarpophalangeal joints are the most commonly involved among all joints. The Achilles and patellar tendons are the leading regions of involvement in tendons. ${ }^{[6]}$ The lesions can be less commonly encountered in the triceps and the extensor tendons. The recurrence tendency of surgically removed Achilles tendon lesions is high $(27 \%) \cdot{ }^{[7]}$

The tendo-calcaneal attachment of the Achilles tendon may swell and lead to pain, loss of function, and shoe-related problems. ${ }^{[8]}$ Patients may experience weakened plantar flexion, which in turn causes
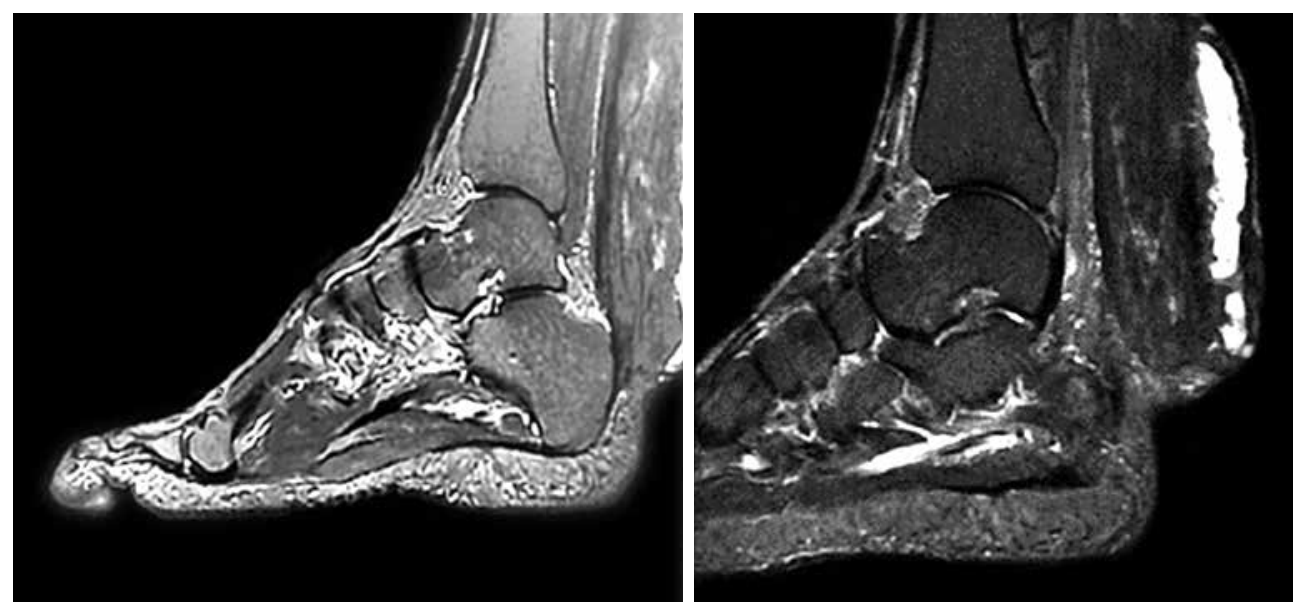

Figure 2. Preoperative $T_{1}$ and $T_{2}$-weighted magnetic resonance images of the right and left ankles. Diffuse swelling of the Achilles tendon and areas within the mass shows increased signal intensity. 

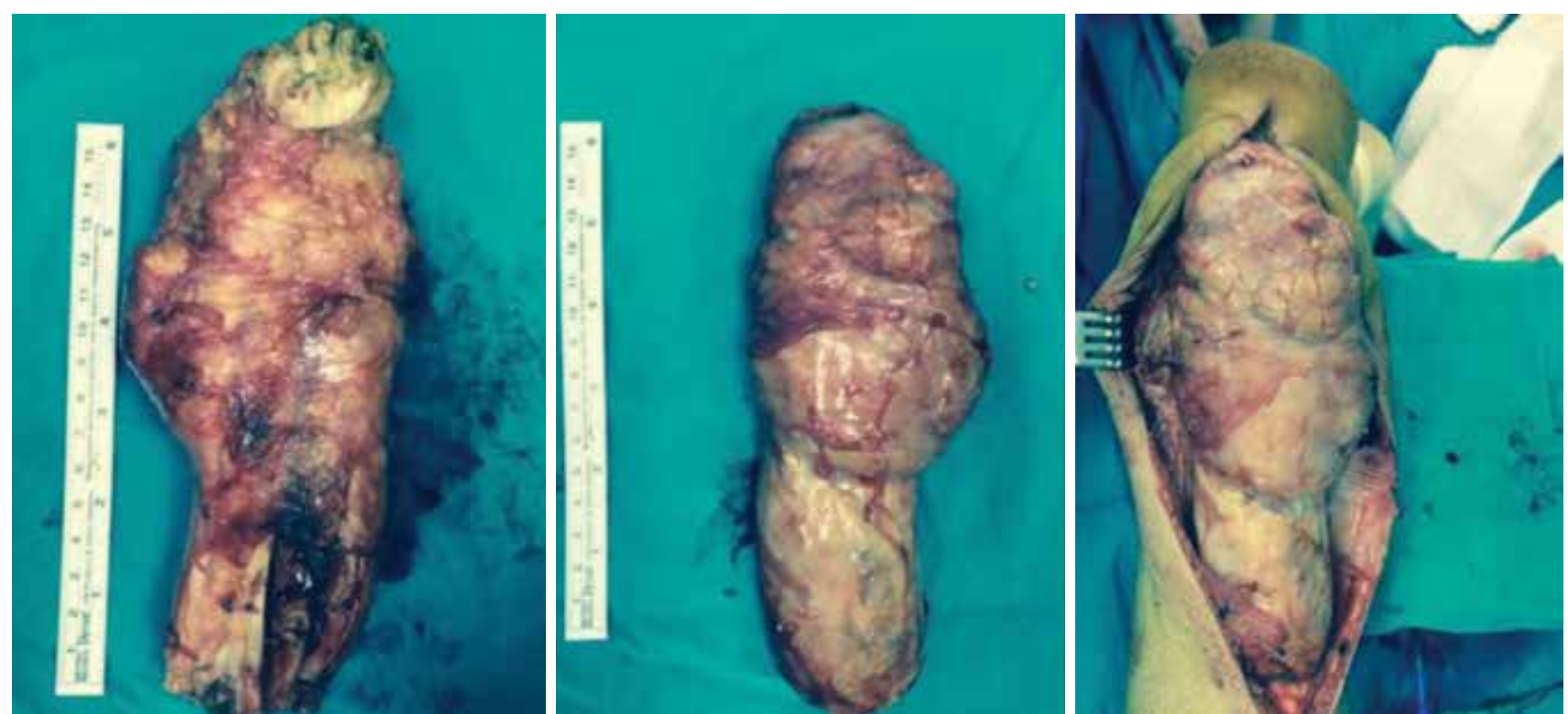

Figure 3. Masses resected from the left (the larger mass) and right ankles. Intraoperative appearance of the mass in the right ankle.

difficulty walking. Extended surgical approaches are often required. In order to minimize the disintegration of the xanthomatous mass surrounded by a capsule, gentle and blunt dissection should be performed. Extended approaches enable better exposure of xanthomas.

In this study, we present a case of bilateral Achilles tendon xanthomas secondary to $\mathrm{FH}$, which were resected together with a portion of the Achilles tendon. With the use of flexor hallucis longus (FHL) tendon transfer and the quadriceps tendon autograft, which contained autologous bone fragments, the reconstruction of the Achilles tendon was performed in both ankles and movement functionality was regained. ${ }^{[9]}$ The patient was followed up on for two years postoperatively. No recurrence was observed, and the ankles gained normal functionality.

\section{CASE REPORT}

A 49-year-old male patient presented to our clinic with complaints of difficulty walking and swelling in both heels. The patient's history revealed the onset of the swellings dating 20 years back. The swellings had began insidiously without a trauma history
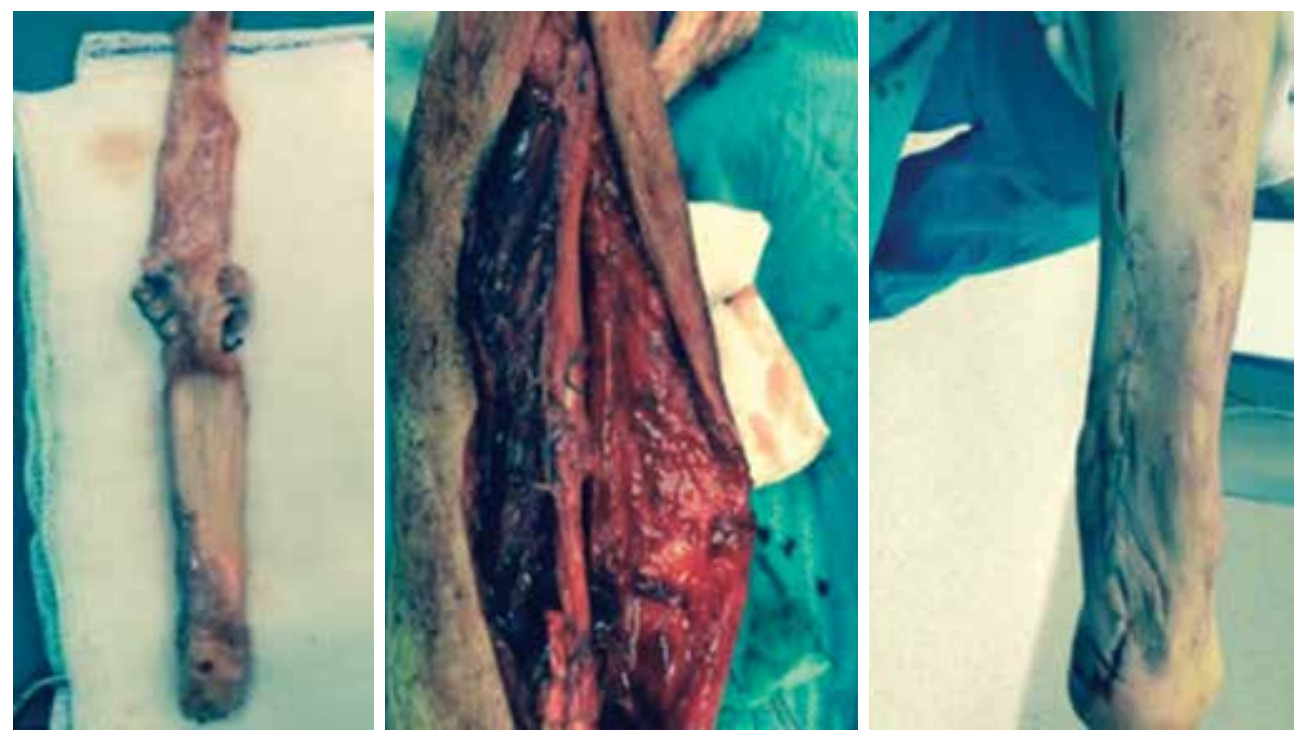

Figure 4. The harvested tendon graft and the right ankle after reconstruction. 

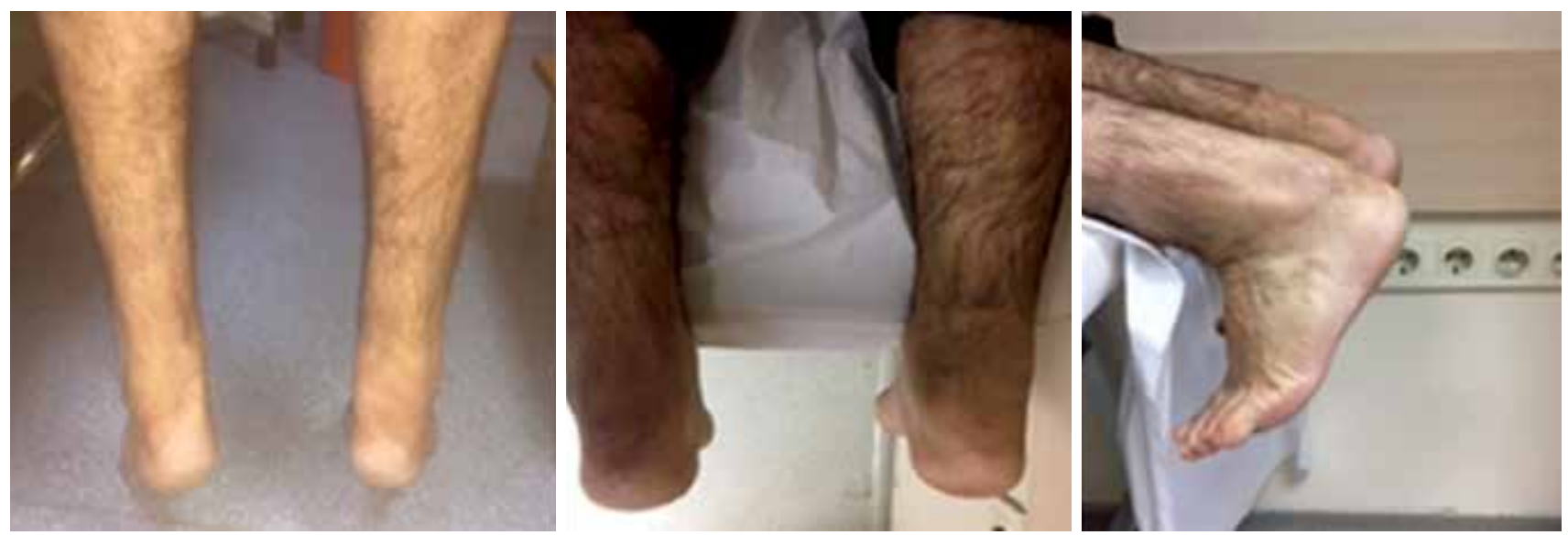

Figure 5. Photos from the second year follow-up examination. The patient could stand on his tiptoes on both sides.

and were progressive. Dorsiflexion was limited in both ankles. Both feet had Stage 1 cavus deformity and the swellings had no ulcers. The patient could walk about 300 meters. A review of the patient's history revealed no classical symptoms of CTX, such as a cataract surgery or chronic diarrhea, nor any neurological pathology. However, the patient had a familial history of FH. His parents were first-degree relatives. The patient had a sister and two brothers, one of them had small sized xanthomas on his ankles and hands. The patient was diagnosed with bilateral Achilles tendon xanthoma secondary to FH using magnetic resonance imaging (MRI). The diagnosis was confirmed with bilateral closed tru-cut biopsy performed under sedation analgesia in the operating room. The patient had a short-stepping gait. There was no heel to toe progression. A written informed consent was obtained from the patient.

Before operation, the patient's AOFAS (American Orthopaedic Foot and Ankle Society) score 10 was 92/100.

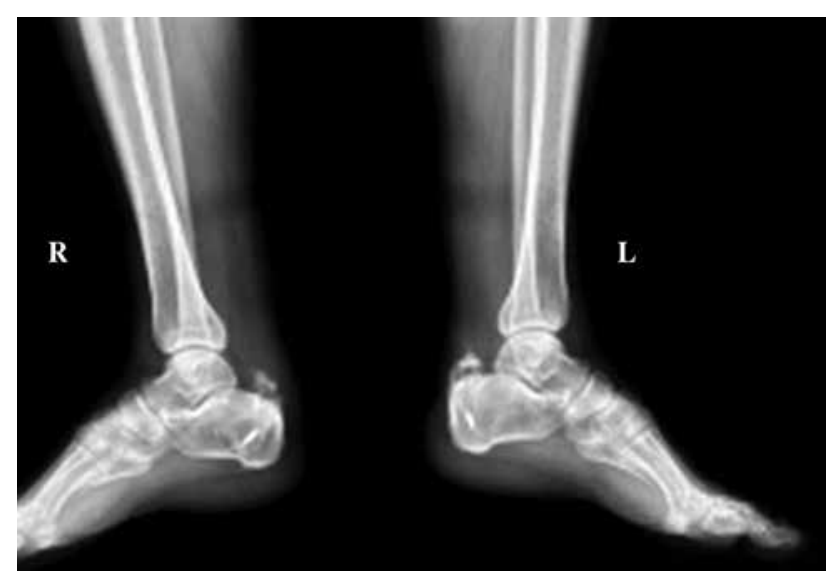

Figure 6. Postoperative X-rays of the left and right ankles.
Preoperative laboratory findings were as follows; blood count was within normal values, sedimentation: 4 (normal), blood glucose: $90 \mathrm{mg} / \mathrm{dL}$ (normal), uric acid: $5.69 \mathrm{mg} / \mathrm{dL}$ (normal) (reference range: 3.5-7.2), cholesterol: $225 \mathrm{mg} / \mathrm{dL}$ (high) (reference range: 0-200), triglycerides: $172 \mathrm{mg} / \mathrm{dL}$ (normal) (reference range: 0-200), HDL cholesterol: $58 \mathrm{mg} / \mathrm{dL}$ (high) (reference range: $0-55)$ and LDL cholesterol: $133 \mathrm{mg} / \mathrm{dL}$ (high) (reference range: 60-130).

Radiography showed no bone pathology (Figure 1). In the MRI of the right ankle, a large lesion with an axial diameter of $75 \times 43 \mathrm{~mm}$ showing a craniocaudal extension of $180 \mathrm{~mm}$ was detected on the distal tibia and posterior aspect of the ankle. The lesion had greatly surrounded the Achilles tendon from the posterolateral and contained sporadic tendon ligaments. Contrast imaging showed no enhancement. The lesion filled the subcutaneous fatty tissue and extended toward the posterior adjacency of the soleus muscle. The described lesion was confirmed and reported as xanthoma.

In the MRI of the left ankle, a mass was found in the left distal cruris starting from the soleus muscle and Achilles tendon junction in the posterior aspect and extending to the posterior adjacency of the calcaneus and behind the Achilles tendon in a fusiform manner. The size of the mass lesion was $155 \mathrm{~mm}$ where its craniocaudal continuity was most significant and had an axial diameter of $66 \times 42 \mathrm{~mm}$. The mass involved the majority of the Achilles tendon, and the Achilles tendon ligaments showed sporadic disburse within the mass. The Achilles tendon could not be clearly distinguished from the mass. The findings were in concordance with those of xanthoma (Figure 2). The MRI findings required a biopsy of the mass. 
For the medical treatment of this high-lipid profile patient, $10 \mathrm{mg} /$ day atorvastatin was preoperatively administered. The swellings in both Achilles tendons were intervened at different time periods.

The lesion on the left side was operated 10 days after the closed biopsy. The operation was initiated with the patient placed in the supine position and under epidural anesthesia. The left quadriceps tendon was partially trimmed to harvest a tendon autograft strip of $11 \mathrm{~cm}$. The patient was then placed in the prone position. An incision of $20 \mathrm{~cm}$ was performed, entering the mass from the posterior of the left ankle. The mass had completely invaded the Achilles tendon. The mass was resected together with the Achilles tendon and was sent for pathological evaluation (Figure 3).

In the left ankle, the FHL tendon was identified and tenotomized through the talar tunnel. The harvested quadriceps autograft was fixed on the distal calcaneus using FiberWire sutures (Arthrex Inc., Naples, FL, USA), with the ankle placed in the equine position. The distal tendons were fixed with non-absorbable sutures. A bioabsorbable screw was fixed in the tunnel opened in the calcaneus at the distal of the FHL tendon and with the ankle in the appropriate equine position. The now neighboring quadriceps graft and FHL tendons were sutured to each other (Figure 4). During the preoperative examination, the patient had normal plantar flexion. The incision was closed after placing a Hemovac drain and a short-leg cast was applied.

The pathology report of the left ankle confirmed the yellow-colored mass, $17.5 \times 6.5 \times 4.5 \mathrm{~cm}$ in size, and with a capsulated and glossy appearance on one side and with tendon sheaths containing fatty regions on the other side as xanthoma.

Approximately two months after the surgery, the patient underwent a mass excision and tendon reconstruction of the right ankle using the same techniques employed for the left side. The excised mass was sent for pathological evaluation. The pathology report confirmed the yellow-colored, glossy mass of $10.5 \times 4.6 \times 4.1 \mathrm{~cm}$ as xanthoma.

Casts on both ankles were kept for four weeks postoperatively. Partial weight-bearing on both ankles was performed on the sixth week, and shortleg walking casts were applied. Full weight-bearing was allowed two months after surgery.

Both ankles were clinically evaluated 24 months post surgery. Both ankles had a dorsiflexion of about $20^{\circ}$ and plantar flexion of about $40^{\circ}$. The muscle strength in both ankles was 5/5. There was no calf muscle atrophy. The patient was able to walk without a calcaneus limp and could stand on tiptoes without support. He reached normal levels of physical activity at home and at work (Figure 5).

Postoperative laboratory findings were as follows; cholesterol: $133 \mathrm{mg} / \mathrm{dL}$ (normal) (reference range: 0-200), triglycerides: $157 \mathrm{mg} / \mathrm{dL}$ (normal) (reference range: 0-200), HDL cholesterol: $51 \mathrm{mg} / \mathrm{dL}$ (normal) (reference range: 0-55) and LDL cholesterol: $51 \mathrm{mg} / \mathrm{dL}$ (normal) (reference range: 60-130).

The AOFAS score 10 of the patient was 96/100 (postoperative). The lesion showed no clinical recurrence at the second year follow-up. Both ankles have regained their functionality.

\section{DISCUSSION}

Xanthomas are defined as tumors or pseudotumors of the connective tissue, and consist of histiocytes with lipid deposits. These tumors manifest themselves as lobular masses with a well-capsulated and yellow appearance. Comorbidity of xanthomas and FH is typical, as was the case in our study where the plasma lipid levels had increased.

Xanthomas of the ankle are rarely seen and always manifest themselves as multiple lesions. They tend to recur if total resection is not performed. ${ }^{[1]}$ Although xanthomas occur due to the deterioration of lipid metabolism, the lesions may be encountered in patients without hypercholesterolemia. ${ }^{[10]}$ The lesions usually involve the extensor tendon of the metacarpophalangeal joints. ${ }^{[10]}$ The Achilles tendon is involved in $50 \%$ of the patients. ${ }^{[7]}$ In our case, the lesion in the left ankle measured $17.5 \mathrm{~cm}$ and in the right ankle $10.5 \mathrm{~cm}$. The largest xanthoma of the ankle ever reported was $22 \mathrm{~cm}$ in size and was reported. ${ }^{[7]}$

The treatment primarily focuses on decreasing serum cholesterol levels. Similarly, we initiated a medical treatment before surgery in an attempt to decrease the patient's cholesterol level. The lesion has to be removed surgically in some patients when the mass causes pain, malformation and gait disturbance. ${ }^{[7]}$ Radiation therapy has been proved to be ineffective in the treatment of these lesions. ${ }^{[7]}$ Local excision or subtotal resection of the lesion were reported to lead to recurrence by several authors. ${ }^{[2,7]}$ The rate of recurrence after partial resection of the lesion varies between 12 and $15 \%{ }^{[7]}$ Due to this high rate of recurrence, total resection of the tendon between the musculotendinous junction and the calcaneus was recommended. ${ }^{[1]}$ 
Reconstruction of the Achilles tendon from the musculotendinous junction to the calcaneus remains a surgical challenge. Several procedures have been suggested for tendocalcaneal reconstruction. ${ }^{[11-13]}$ The use of local tendons such as peroneus brevis $(\mathrm{PB})$ and FHL have also been proposed. ${ }^{[14,15]}$ Boopalan et al. ${ }^{[13]}$ recommended the use of free autologous tendon grafts from the gracilis, semitendinosus or tensor fasciae latae (TFL) muscles. Allografts have also been used in reconstruction. ${ }^{[9]}$ In our case, quadriceps tendon graft with bony fragments was used for reconstruction since there was a large defect, and the tendons such as the PB and FHL tendons would not suffice alone. The gracilis, semitendinosus, or TFL tendons do not contain bony fragments, and the TFL tendon graft is much thinner than the other grafts. We believe that using a tendon graft with bony fragments would have augmented the tendo-calcaneal healing (Figure 6). We avoided using an allograft as the cost was too high. In addition, we believe that autografts integrate with the calcaneus better than allografts. Our reconstruction technique has not been employed before, due to the resection of a massive xanthoma of the Achilles tendon.

The postoperative AOFAS score of our patient is concordant with the results of tendocalcaneal reconstruction using allografts in Scagnelli et al.'s study, ${ }^{[14]}$ and Tomita et al.'s study, ${ }^{[1]}$ where the reconstruction was realized using TFL autograft.

Xanthoma should be considered in cases of swellings in the Achilles tendon. Total resection is necessary to avoid recurrence of the lesions. Big gaps formed after resection can be filled and reconstruction of the Achilles tendon can be realized using quadriceps tendon autografts (containing bony fragments) and the FHL tendon. We believe a functional ankle and an Achilles tendon can be achieved with the employment of this technique.

\section{Declaration of conflicting interests}

The authors declared no conflicts of interest with respect to the authorship and/or publication of this article.

\section{Funding}

The authors received no financial support for the research and/or authorship of this article.

\section{REFERENCES}

1. Tomita T, Ochi T, Fushimi H, Matsuzawa Y, Ono K. Reconstruction of the Achilles tendon for xanthoma: findings at operative re-exploration. A case report. J Bone Joint Surg [Am] 1994;76:444-7.

2 Fahey JJ, Stark HH, Donovan WF, Drennan DB. Xanthoma of the achilles tendon. Seven cases with familial hyperbetalipoproteinemia. J Bone Joint Surg [Am] 1973;55:1197-211.

3. Caputo R, Monti M, Berti E, Gasparini G. Normolipemic eruptive cutaneous xanthomatosis.Arch Dermatol 1986;122:1294-7.

4. Brodsky JW, Beischer AD, Anat D, East C, Soltero E, Tint GS, et al. Cerebrotendinous xanthomatosis: a rare cause of bilateral Achilles tendon swelling and ataxia. A case report. J Bone Joint Surg [Am] 2006;88:1340-4.

5. Robson KJ, Piette WW. Cutaneous manifestations of systemic diseases. Med Clin North Am 1998;82:1359-79.

6. Bude RO, Adler RS, Bassett DR. Diagnosis of Achilles tendon xanthoma in patients with heterozygous familial hypercholesterolemia: MR vs sonography. AJR Am J Roentgenol 1994;162:913-7.

7. Friedman MS. Xanthoma of the Achilles tendon. J Bone Joint Surg [Am] 1947;29:760-6.

8. Carranza-Bencano A, Fernádez-Centeno $M$, Leal-Cerro A, Duque-Jimeno V, Gomez-Arroyo JA, Zurita-Gutierrez M. Xanthomas of the Achilles tendon: report of a bilateral case and review of the literature. Foot Ankle Int 1999;20:314-6.

9. Atik OŞ. Which articles do we prefer to publish? Eklem Hastalik Cerrahisi 2018;29:1.

10. Roy S.K, Kumar S.N. Xanthomas of the Achilles tendon- A Case report. Indian Journal of Orthopaedics 1983;17:63-5.

11. Pearce CJ, Sexton S, Gerrard D, Hatrick A, Solan M. Successful treatment of a chronically infected and necrotic tendo Achillis in a diabetic with excision, flexor hallucis longus transfer and split-skin grafting. J Bone Joint Surg [Br] 2008;90:186-8.

12. Gallant GG, Massie C, Turco VJ. Assessment of eversion and plantar flexion strength after repair of Achilles tendon rupture using peroneus brevis tendon transfer. Am J Orthop (Belle Mead NJ) 1995;24:257-61.

13. Boopalan PR, Jepegnanam TS, Titus VT, Prasad SY, Chittaranjan SB. Open infected Achilles tendon injury-reconstruction of tendon with fascia lata graft and soft tissue cover with a reverse flow sural flap. Foot Ankle Surg 2008;14:96-9.

14. Scagnelli R, Bianco G, Imarisio D. Cadaver bone-tendon graft for xanthomatosis of the tendo Achillis. J Bone Joint Surg [Br] 2009;91:968-71

15. Lepow GM, Green JB. Reconstruction of a neglected achilles tendon rupture with an achilles tendon allograft: A case report. J Foot Ankle Surg 2006;45:351-5. 